\title{
Proteomic Analysis of Hippocampus and Cortex in Streptozotocin-Induced Diabetic Model Mice Showing Dementia
}

\author{
Kenji Matsuura, ${ }^{1}$ Mieko Otani, ${ }^{2}$ Masaoki Takano, ${ }^{2}$ Keiichi Kadoyama, ${ }^{3}$ \\ and Shogo Matsuyama ${ }^{4}{ }^{4}$ \\ ${ }^{1}$ Faculty of Pharmacy, Osaka-Ohtani University, Tondabayashi 584-8540, Japan \\ ${ }^{2}$ Department of Life Sciences Pharmacy, School of Pharmaceutical Sciences, Kobe Gakuin University, Kobe 650-8586, Japan \\ ${ }^{3}$ Department of Pharmaceutical Health Care, Faculty of Pharmaceutical Sciences, Himeji Dokkyo University, Himeji 670-8524, Japan \\ ${ }^{4}$ Biosignal Research Center, Kobe University, Kobe 657-8501, Japan
}

Correspondence should be addressed to Shogo Matsuyama; shogo@platinum.kobe-u.ac.jp

Received 8 November 2017; Revised 24 January 2018; Accepted 21 February 2018; Published 5 April 2018

Academic Editor: Hiroshi Okamoto

Copyright $\odot 2018$ Kenji Matsuura et al. This is an open access article distributed under the Creative Commons Attribution License, which permits unrestricted use, distribution, and reproduction in any medium, provided the original work is properly cited.

Aim. Diabetes with its associated hyperglycemia induces various type of peripheral damage and also impairs the central nervous system (CNS). This study is aimed at clarifying the precise mechanism of diabetes-induced dementia as an impairment of CNS. Methods. The proteomic analysis of the hippocampus and cortex in streptozotocin- (STZ-) treated mouse diabetic model showing dementia was performed using two-dimensional gel electrophoresis (2-DE) followed by mass spectrometry $(n=3$ /group). Results. Significant changes in the expression of 32 proteins and 7 phosphoproteins were observed in the hippocampus and cortex. These identified proteins and phosphoproteins could be functionally classified as cytoskeletal protein, oxidoreductase, protein deubiquitination, energy metabolism, GTPase activation, heme binding, hydrolase, iron storage, neurotransmitter release, protease inhibitor, transcription, glycolysis, antiapoptosis, calcium ion binding, heme metabolic process, protein degradation, vesicular transport, and unknown in the hippocampus or cortex. Additionally, Western blotting validated the changes in translationally controlled tumor protein, ATP-specific succinyl-CoA synthetase beta subunit, and gamma-enolase isoform 1 . Conclusions. These findings showed that STZ-induced diabetes changed the expression of proteins and phosphoproteins in the hippocampus and cortex. We propose that alterations in expression levels of these proteins play an important role in diabetesinduced dementia.

\section{Introduction}

Diabetes is a chronic and metabolic disease characterized by hyperglycemia resulting from defective insulin secretion and/or insulin resistance [1]. Diabetics are at a significantly elevated risk for nephropathy, peripheral neuropathy, and retinopathy. In the central nervous system (CNS), chronic hyperglycemia leads to the enhanced formation of advanced glycation end products (AGEs), which have potentially toxic effects on neurons, causing dementia [2]. Hyperglycemia also causes a significant increase in generation of reactive oxygen species (ROS), resulting in cerebral angiopathy and abnormalities of neurons and glia in the brain, and subsequent dementia [3]. The degree to which the neuronal abnormality is caused directly by hyperglycemia remains unclear [3].
Moreover, the development of diabetes-induced dementia is not only closely associated with hyperglycemia but also with the action of insulin [4].

Insulin and insulin receptors show abundant expression throughout the brain, especially in the hippocampus, which is involved in dementia [5]. Peripheral insulin crosses the blood-brain barrier (BBB) via an active transport mechanism to exert its effects within the CNS [6]. Insulin receptors in the brain are found at synapses on both neurons and astrocytes [7]. Insulin signaling acts as a neuromodulator that regulates the release and reuptake of neurotransmitters, such as acetylcholine and norepinephrine in rat locus coeruleus [8], and regulates neuronal and glial functions such as synaptogenesis and synaptic plasticity via energy homeostasis, gene expression, and cognition [9]. Interestingly, insulin administered 
by intranasal improved cognitive dysfunction and insulin signaling, reduced amyloid- $\beta(\mathrm{A} \beta)$ production and amyloid plaque burden, and increased neurogenesis in 4-month-old APP/PS1 mice showing early Alzheimer's disease (AD) pathologies [10]. Furthermore, intranasal insulin application improved cognitive performance in healthy subjects, aged subjects, AD patients, and experimental models of insulin resistance [11]. In the brain, insulin-degrading enzyme (IDE) is synthesized and secreted by neurons, oligodendrocytes, and microglia [12]. IDE degrades extracellular $\mathrm{A} \beta$ in microglial and neuronal cultures and insulin can prevent this degradation, thereby impairing the clearance of extracellular $\mathrm{A} \beta$ [13]. IDE mutant rats, which show reduced activity of the enzyme, lead to type 2 diabetes, resulting in the enhanced cerebral deposition of $\mathrm{A} \beta$ [14]. However, to clarify the precise mechanisms involved in the development of diabetesinduced dementia, further research will be required.

Streptozotocin (STZ), a glucosamine-nitrosourea compound, is a genotoxic methylating agent and preferentially destroys insulin-producing $\beta$ cells of the pancreas through the generation of ROS and alkylation of DNA [15]. STZ is a chemical used for the generation of diabetes phenotypes in most strains of rodents [16]. A mouse model utilizing five doses of STZ at low dose (50-60 mg/kg/day) has been extensively used in studies of type 1 diabetes (T1D) due to the progressive destruction of pancreatic $\beta$ cells induced [17]. Importantly, the STZ-induced diabetes of mouse resulted in spatial learning deficits and impaired hippocampal longterm potentiation (LTP), which is thought to affect the cellular mechanisms of learning and memory [18]. Accordingly, STZ-treated mice have been used extensively to examine the physiological and pathophysiological consequences of diabetes-induced dementia.

In the present study, changes in the expression of hippocampal and cortical proteins and phosphoproteins in STZ-treated mice were examined using two-dimensional gel electrophoresis followed by staining with SYPRO Ruby and Pro-Q Diamond, respectively, and subsequent mass spectrometry to elucidate the molecular mechanisms involved in diabetes-induced dementia.

\section{Materials and Methods}

2.1. Reagents. Streptozotocin (STZ), urea, thiourea, sodium dodecyl sulfate (SDS), 3-((3-cholamidopropyl) dimethylammonio)-1-propanesulfonate (CHAPS), 2-mercaptoethanol (2-ME), dithiothreitol (DTT), bromophenol blue, iodoacetamide, RNase A, and DNase I were purchased from Wako Pure Chemical Industries, Ltd. (Osaka, Japan). Source information for all other assay reagents and materials is stated in the Materials and Methods section described below.

2.2. Animals. C57BL/6 mice (Japan SLC, Inc., Shizuoka, Japan) were maintained in a standard $12 \mathrm{~h}$ light/dark environment (lights on at 7:00 A.M.). Food and water were available to mice ad libitum. All experimental procedures were performed in accordance with the National Institutes of Health Guidelines on the Care and Use of Animals and confirmed by the Himeji Dokkyo University Animal Experiment
Committee. All efforts were made to minimize animal use and suffering.

2.3. Generation of Diabetic Model Mice. The diabetic model was set up by intraperitoneal injection of STZ $50 \mathrm{mg} / \mathrm{kg}$ once a day for 5 consecutive days [19]. Ten weeks after injection, the mice were tested for sufficient levels of hyperglycemia. Blood glucose level was assessed using blood glucometer (Terumo Co. Tokyo, Japan) by tail vein puncture blood sampling. A serum glucose level higher than $400 \mathrm{mg} / \mathrm{dl}$ was considered diabetic [20].

2.4. Protein Extraction. Protein extraction was performed as previously described [21]. Both the STZ- and vehicle-treated mice were killed under anesthesia with pentobarbital sodium. The hippocampi and cortices were isolated from three mice in each group, and mixed separately for the two groups. Two-DE analysis was repeated in triplicate. In brief, mouse hippocampal samples were homogenized in lysis buffer [7 M urea, $2 \mathrm{M}$ thiourea, 5\% CHAPS, 2\% immobilized $\mathrm{pH}$ gradient (IPG) buffer (GE Healthcare UK Ltd., Buckinghamshire, UK), $50 \mathrm{mM} 2-\mathrm{ME}, 2.5 \mu \mathrm{g} / \mathrm{ml}$ DNase I, and $2.5 \mu \mathrm{g} / \mathrm{ml}$ RNase A]. Solubilized extracts were centrifuged at $15,000 \times \mathrm{g}$ for $30 \mathrm{~min}$, and the supernatant was used for further analysis.

2.5. Two-DE. Two-DE analysis was carried out as previously described [21, 22]. In brief, one-dimensional isoelectric focusing (IEF) gel electrophoresis was performed using IPG gel strips ( $\mathrm{pH} 4-7 ; 7 \mathrm{~cm}$; GE Healthcare, WI). Approximately $1000 \mu \mathrm{g}$ of protein from each group was incubated with the IPG strips and run at $50 \mathrm{~V}$ for $6 \mathrm{~h}$, at $100 \mathrm{~V}$ for $6 \mathrm{~h}$, and finally at $2000 \mathrm{~V}$ for $6 \mathrm{~h}$. After IEF gel electrophoresis, the IPG strips were equilibrated for $15 \mathrm{~min}$ in equilibration buffer [ $50 \mathrm{mM}$ Tris- $\mathrm{HCl}, \mathrm{pH} 8.8,6 \mathrm{M}$ urea, $1 \%$ SDS, 30\% (v/v) glycerol, and $1 \%(\mathrm{w} / \mathrm{v}) \mathrm{DTT}]$ and then for $15 \mathrm{~min}$ in equilibration buffer containing $2.5 \%(\mathrm{w} / \mathrm{v})$ iodoacetamide instead of DTT. For the second dimension, the equilibrated IPG strips were transferred onto $15 \%$ SDS-PAGE gels at $5 \mathrm{~mA} / \mathrm{gel}$ for $7 \mathrm{~h}$.

2.6. Protein or Phosphoprotein Staining and Image Acquisition. Protein or phosphoprotein gel staining and image acquisition were carried out as previously described $[21,22]$. Briefly, the gels were fixed three times in $200 \mathrm{ml}$ immobilization solution [10\% acetic acid and 50\% methanol] for $30 \mathrm{~min}$ and washed five times with $200 \mathrm{ml}$ of water for 15 min. Under the dark, the gels were stained with Pro-Q Diamond phosphoprotein gel stain (Life Technologies, Carlsbad, CA) for $120 \mathrm{~min}$ at room temperature with gentle agitation and then washed three times with destaining solution [ $50 \mathrm{mM}$ sodium acetate, $\mathrm{pH} 4.0$ and $20 \%(\mathrm{v} / \mathrm{v})$ acetonitrile] for $30 \mathrm{~min}$. Image acquisition was performed on Fluorophorestar 3000 image capture system (Anatech, Tokyo, Japan) with a $520 \mathrm{~nm}$ excitation and $575 \mathrm{~nm}$ emission filter for Pro-Q Diamond detection.

Next, gels were washed with washing solution $[10 \%$ methanol and 7\% acetic acid] for $30 \mathrm{~min}$. The gels were incubated in SYPRO Ruby stain (Life Technologies) for $90 \mathrm{~min}$ in the dark. The gels were washed with destaining solution $[10 \%$ 
methanol and 7\% acetic acid] for $30 \mathrm{~min}$ and rinsed with MilliQ $\mathrm{H}_{2} \mathrm{O}$. Image acquisition was carried out using a Fluorophorestar 3000 image capture system with a $470 \mathrm{~nm}$ excitation and $618 \mathrm{~nm}$ emission filter for SYPRO Ruby detection.

2.7. Image Analysis. Image analysis was performed as previously described $[21,22]$. Image analysis and the quantification of gel spots were performed with Prodigy SameSpots software (Nonlinear Dynamics, Newcastle upon Tyne, UK). From the menu of SameSpots normalization options, we chose to normalize the intensity of each spot to the total intensity of all matched spots within each gel and to identify differentially expressed spots by comparing spot intensity differences between samples from STZ-treated mice and control mice using ANOVA.

2.8. Trypsin Digestion. In-gel digestion was performed using a method described [21]. Protein spots were cut from the gels, and the gel pieces were washed three times for $15 \mathrm{~min}$ each with $200 \mu \mathrm{l}$ of $50 \mathrm{mM}$ ammonium bicarbonate with $50 \%(\mathrm{v} / \mathrm{v})$ acetonitrile and then dried under vacuum. The gel piece was rehydrated in $5 \mu \mathrm{l}$ of sequencing-grade modified trypsin (10 ng/ $\mu$ l, Promega, Madison, WI) in $10 \mathrm{mM}$ ammonium bicarbonate for $30 \mathrm{~min}$ at $4^{\circ} \mathrm{C}$, and digestion was carried out for $18 \mathrm{~h}$ at $37^{\circ} \mathrm{C}$. Peptides were extracted with $5 \mu \mathrm{l}$ of extracting solution $[50 \%(\mathrm{v} / \mathrm{v})$ acetonitrile and $0.3 \%(\mathrm{v} / \mathrm{v})$ trifluoroacetic acid] for $10 \mathrm{~min}$ by sonication.

\subsection{Mass Spectrometry Analysis and Protein Identification.} Mass spectrometry analysis was performed in accordance with the procedure described in our previous report [21]. In brief, mass spectra were obtained using a MALDI-TOF MS/MS analyzer (ABI PLUS 4800, Applied Biosystems, Foster City, CA). One $\mu \mathrm{l}$ of each sample was mixed with $1 \mu \mathrm{l}$ matrix solution $[1 \mu \mathrm{g} / \mu \mathrm{l} \alpha$-cyano-4-hydroxycinnamic acid (CHCA, Wako Pure Chemical Industries Ltd.) in $50 \%(\mathrm{v} / \mathrm{v})$ acetonitrile and $0.3 \%(\mathrm{v} / \mathrm{v})$ trifluoroacetic acid]. Analyte and matrix were spotted onto a stainless steel MALDI target plate and dried under ambient conditions. The peptides were analyzed using a MALDI-TOF MS/MS analyzer, and the authors searched the database with the Mascot search engine (http://www.matrixscience.com; Matrix Science, Boston, MA) using a Mascot MS/MS ion search through NCBInr databases. Proteins were considered as identified by MALDI-TOF MS if they had Mascot scores of 60 or higher $(P<0.05)$.

2.10. Western Blotting. The isolated hippocampus and cortex samples were homogenized in buffer containing $20 \mathrm{mM}$ Tris-HCl, pH 7.0, $6 \mathrm{M}$ urea, $150 \mathrm{mM} \mathrm{NaCl}, 2 \mathrm{mM}$ EDTA, and $1 \%$ Triton $\mathrm{X}-100$. The homogenates were subjected to $8 \%$ SDS-polyacrylamide gel electrophoresis and analyzed by Western blot using rabbit anti-TCTP (diluted $1: 1000$, Abcam, Cambridge, MA), rabbit anti-SUCLA2 (diluted $1: 1000$, Abcam), rabbit anti-NSE (diluted $1: 1000$, Abcam), and rabbit anti-GAPDH (diluted 1:10,000, AbFrontier, Seoul, Korea) antibodies at $4^{\circ} \mathrm{C}$ overnight. The membranes were incubated with the indicated secondary antibody (diluted 1:5000, GE Healthcare, Madison, WI). All values were corrected with reference to the value for GAPDH, used as an internal standard. Immunoreactivity was detected by using an Amersham ECL Prime Western blotting detection kit (GE Healthcare). Western blot images were quantified using the Multi Gauge version 2.2 software (Fuji Photofilm, Tokyo, Japan).

2.11. Statistical Analysis. Respective densitometric quantifications are shown as mean \pm SEM. All data were tested by oneway ANOVA followed by Dunnett's multiple-comparisons tests to evaluate the differences between groups. $P<0.05$ was considered statistically significant.

\section{Results}

The expression changes of proteins and phosphoproteins in the hippocampus and cortex of STZ-treated and untreated control mice were quantified and identified on 2-DE gels using Prodigy SameSpot software and MALDI-TOF MS/ MS. Image analysis showed approximately 400 protein spots and 200 phosphoprotein spots on each SYPRO Rubystained 2-DE gel (Figure 1) and each Pro-Q Diamondstained 2-DE gel (Figure 2), respectively. We detected 16 (5 up- and 11 downregulated) hippocampal proteins (Table 1), 16 (7 up- and 9 downregulated) cortical proteins (Table 2), 3 (1 up- and 2 downregulated) hippocampal phosphoproteins (Table 3 ), and 4 ( 2 up- and 2 downregulated) cortical phosphoproteins (Table 3). These proteins and phosphoproteins were categorized into functional groups as shown in Tables 1-3 using the PANTHER (http://www.pantherdb. org/) database.

\subsection{Identification of Altered Proteins and Phosphoproteins} in the Hippocampus of STZ-Treated Mice. The 5 proteins with increased expression levels were identified as type II peroxiredoxin 1, ATP-specific succinyl-CoA synthetase beta subunit, rho GDP-dissociation inhibitor 1, heme-binding protein, and phosphatidylethanolamine-binding protein 1, and the 11 proteins with decreased expression levels were identified as profilin-2, tubulin beta- 5 chain, alpha-internexin, ketimine reductase mu-crystallin, L-lactate dehydrogenase $B$ chain isoform 1 , ubiquitin carboxy-terminal hydrolase L1, isoform CRA_a, proteasome subunit alpha type-3, N(G),N(G)dimethylarginine dimethylaminohydrolase 1 , ferritin heavy chain, translationally controlled tumor protein, and prohibitin (Table 1).

The phosphoprotein with increased expression level was identified as dihydropyrimidinase-related protein 2 , and 2 phosphoproteins with decreased expression level were identified as proteasome subunit alpha type- 3 and beta-soluble NSF attachment protein (Table 2).

3.2. Identification of Proteins and Phosphoproteins with Altered Expression in the Cortex of STZ-Treated Mice. The 7 proteins with increased expression levels were identified as alpha-tubulin, partial, tubulin alpha-1C chain, put. Betaactin (aa 27-375), gamma-actin, alpha-internexin, beta-synuclein, and unnamed protein product, and the 9 proteins with decreased expression levels were identified as tubulin beta- 5 chain, NADH dehydrogenase (ubiquinone) Fe-S protein 1, atp5b protein, partial, gamma-enolase isoform 1 , calretinin, 


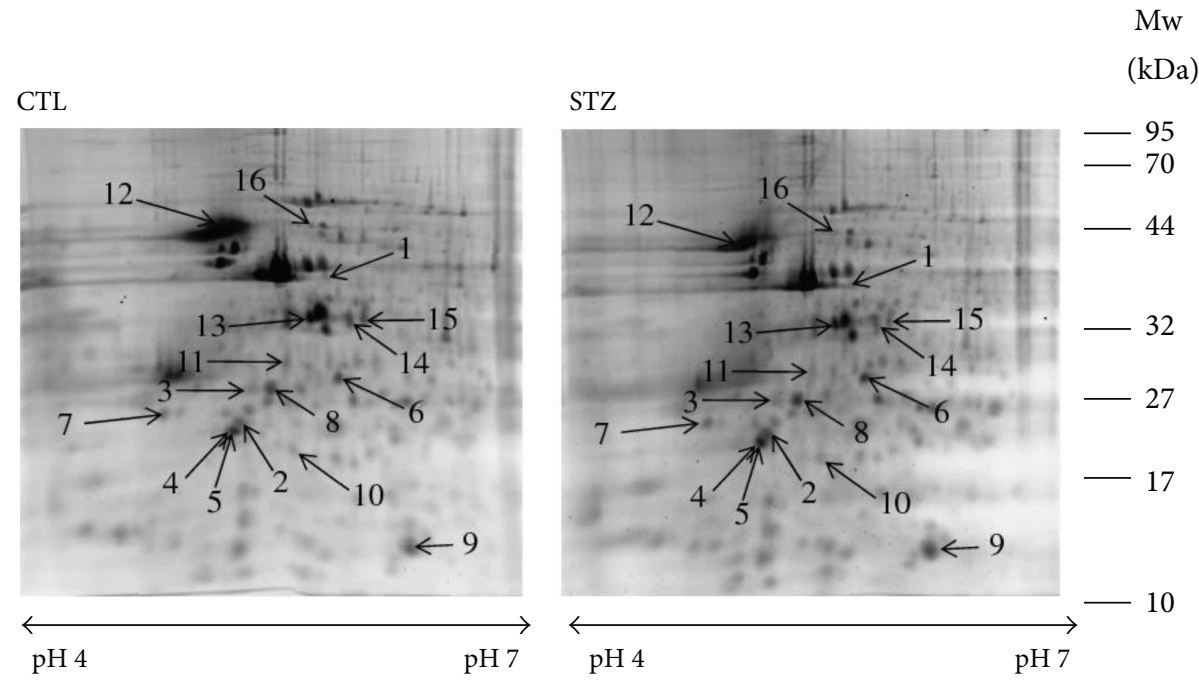

(a)
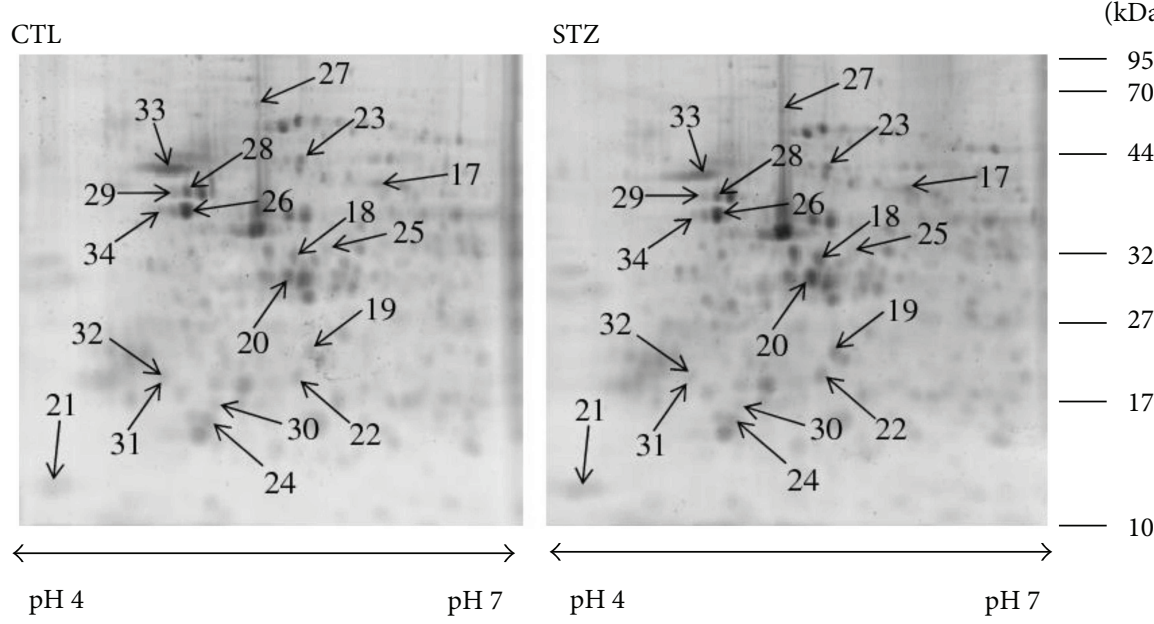

(b)

FIGURE 1: Two-DE images of hippocampal (a) and cortical (b) proteins in STZ-treated (STZ) and control (CTL) mice. IPG strips (pH 4-7) were used for the first dimension, and $15 \%$ polyacrylamide gels were used for the second dimension. Isoelectric points (PIs) and experimental masses are shown on the $x$ - and $y$-axes. The differentially expressed proteins are identified by numbers that correspond to spot numbers in Tables 1 and 3. Experiments were repeated three times independently with similar results. Typical gel images are shown.

heme-binding protein, phosphatidylethanolamine-binding protein 1, COP9 signalosome complex subunit 4, and ubiquitin C-terminal hydrolase L3 (Table 3).

The 2 phosphoproteins with increased expression levels were identified as dihydropyrimidinase-related protein 2 and enolase $1 \mathrm{~B}$, retrotransposed, and the 2 phosphoproteins with decreased expression levels were identified as gammaactin and proteasome subunit alpha type-3 (Table 2).

3.3. Western Blot Analysis of the Altered Proteins in the Hippocampus and Cortex of STZ-Treated Mice. Western blot analysis was performed to validate the identity of translationally controlled tumor protein and ATP-specific succinyl-CoA synthetase beta subunit as differentially expressed hippocampal proteins and the identity of gamma-enolase isoform 1 as differentially expressed cortical protein. The protein level of translationally controlled tumor protein was significantly decreased about 0.8 -fold in the hippocampus of STZtreated mice compared with untreated control $(P=0.049)$ (Figure 3(a)). The protein level of hippocampal ATPspecific succinyl-CoA synthetase beta subunit tended to increase $(P=0.29)$ (Figure $3(b))$ and that of cortical gamma-enolase isoform 1 tended to decrease $(P=0.057)$ (Figure 3(c)).

\section{Discussion}

In this study, we used 2-DE coupled with MS to investigate changes in the expression of proteins and phosphoproteins in the hippocampus and cortex of STZ-treated mice, that 


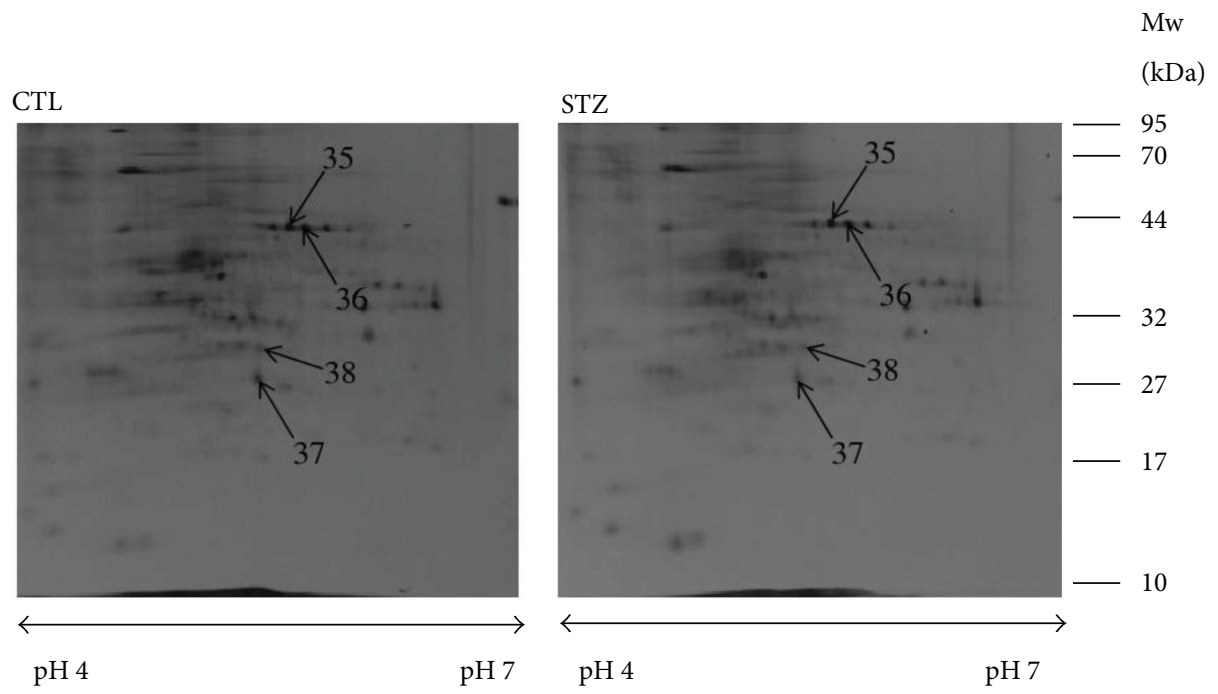

(a)

CTL

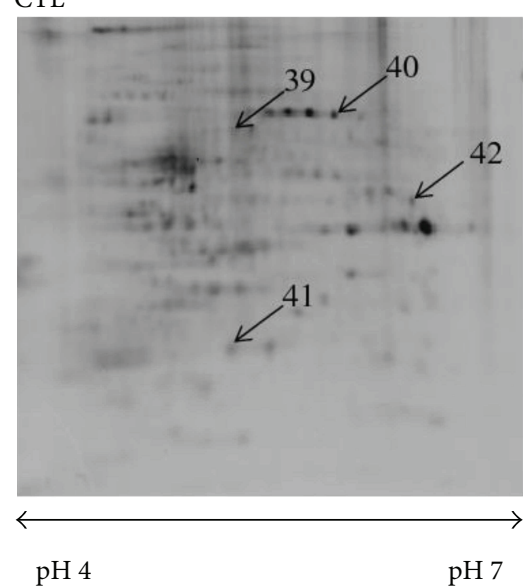

$\mathrm{Mw}$

STZ

(kDa)

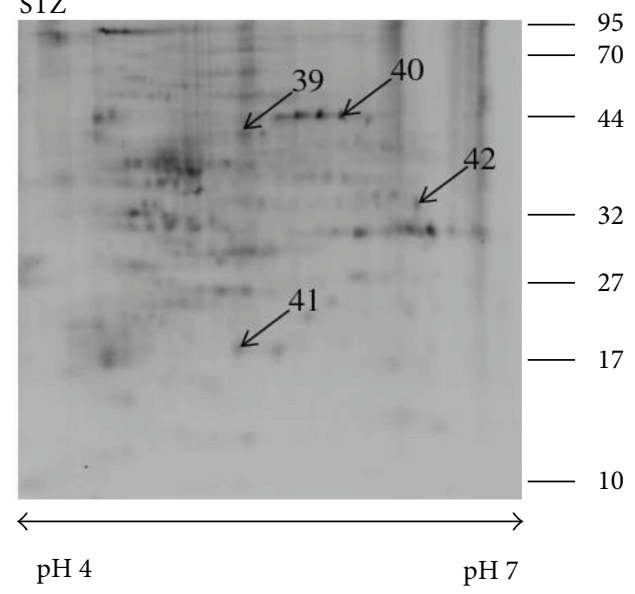

(b)

FIgURE 2: Two-DE images of hippocampal (a) and cortical (b) phosphoproteins in STZ-treated (STZ) and control (CTL) mice. IPG strips ( $\mathrm{pH} 4-7)$ were used for the first dimension, and 15\% polyacrylamide gels were used for the second dimension. Isoelectric points (PIs) and experimental masses are shown on the $x$ - and $y$-axes. The differentially expressed phosphoproteins are identified by numbers that correspond to spot numbers in Table 2. Experiments were repeated three times independently with similar results. Typical gel images are shown.

is, diabetic model mice showing dementia, and revealed that the expression of 32 proteins and 7 phosphoproteins changed significantly.

4.1. Cellular Cytoskeleton. Micorotubules are composed of $\alpha$ and $\beta$-tubulin heterodimers and are present throughout neuronal dendrites and axons. Microtubule dynamics regulate axonal outgrowth, dendritic spine morphology, and synaptic plasticity [23]. Treatment with paclitaxel, a microtubule dynamics inhibitor, leads to LTP deficits in the corticoamygdala pathway in mouse brain slices [24]. Actin exists in both monomeric (G-actin) and polymerized (F-actin) forms and presents in dendritic spines. Actin dynamics are essential in synaptic function and memory formation [25].
Indeed, cytochalasin $\mathrm{D}$, an inhibitor of F-actin polymerization, blocks the late phase of LTP but not the early phase [26]. Thus, changes in the expression of tubulin and actin might affect synaptic plasticity, being involved with diabetes-induced dementia.

4.2. Oxidoreductase. Peroxiredoxins (Prxs) are antioxidant enzymes that contain one or two cysteine (Cys) residues in their active site [27]. There are six isoforms divided into three groups: the 2-Cys Prxs (Prx 1, 2, 3, and 4), the atypical 2-Cys Prx (Prx 5), and the 1-Cys Prx (Prx 6) [27]. In neurons, intracellular Prxs, which are induced by various oxidative stimuli, protect against oxidative radical damage by ROS [28]. Type II Prx 1, also known as Prx 2, is predominantly 
TABLE 1: Identified proteins in the hippocampus and their functional categories.

\begin{tabular}{|c|c|c|c|c|c|c|c|c|}
\hline Spot no. & $\begin{array}{l}\text { Accession } \\
\text { no. }\end{array}$ & Identified protein & $\begin{array}{c}\text { Observed Mw } \\
(\mathrm{kDa}) / \mathrm{pI}\end{array}$ & $\begin{array}{l}\text { Theoretical } \\
\mathrm{Mw}(\mathrm{Da}) / \mathrm{pI}\end{array}$ & Score & SC & $\begin{array}{l}\text { Fold change } \\
\text { (STZ/CTL) }\end{array}$ & $\begin{array}{l}\text { ANOVA } \\
P \text { value }\end{array}$ \\
\hline \multicolumn{9}{|c|}{$\begin{array}{l}\text { Cytoskeletal } \\
\text { protein }\end{array}$} \\
\hline 9 & gi|9506971 & Profilin-2 & $12 / 6.2$ & $15,364 / 6.55$ & 145 & 28 & 0.8 & 0.048 \\
\hline 12 & gi|7106439 & Tubulin beta- 5 chain & $43 / 5.0$ & $50,095 / 4.78$ & 295 & 14 & 0.8 & 0.012 \\
\hline 16 & gi|508538 & Alpha-internexin & $43 / 5.6$ & $56,007 / 5.16$ & 232 & 14 & 0.7 & 0.013 \\
\hline \multicolumn{9}{|c|}{ Oxidoreductase } \\
\hline 5 & gi|3603241 & Type II peroxiredoxin 1 & $21 / 5.1$ & $21,949 / 5.20$ & 136 & 9 & 1.1 & 0.032 \\
\hline 13 & gi|7710012 & Ketimine reductase mu-crystallin & $32 / 5.6$ & $33,673 / 5.44$ & 208 & 14 & 0.8 & 0.002 \\
\hline 15 & gi|6678674 & $\begin{array}{l}\text { L-Lactate dehydrogenase B chain } \\
\text { isoform } 1\end{array}$ & $32 / 5.9$ & $36,834 / 5.70$ & 233 & 14 & 0.7 & 0.041 \\
\hline \multicolumn{9}{|c|}{$\begin{array}{l}\text { Protein } \\
\text { deubiquitination }\end{array}$} \\
\hline 8 & gi|148705825 & $\begin{array}{l}\text { Ubiquitin carboxy-terminal } \\
\text { hydrolase L1, isoform CRA_a }\end{array}$ & $26 / 5.3$ & $24,977 / 5.05$ & 221 & 21 & 0.9 & 0.018 \\
\hline 11 & gi|261824000 & Proteasome subunit alpha type- 3 & $28 / 5.4$ & $28,615 / 5.29$ & 201 & 17 & 0.8 & 0.043 \\
\hline \multicolumn{9}{|c|}{$\begin{array}{l}\text { Energy } \\
\text { metabolism }\end{array}$} \\
\hline 1 & gi|3766201 & $\begin{array}{l}\text { ATP-specific succinyl-CoA } \\
\text { synthetase beta subunit }\end{array}$ & $37 / 5.7$ & $46,557 / 5.65$ & 170 & 8 & 1.8 & 0.014 \\
\hline \multicolumn{9}{|c|}{$\begin{array}{l}\text { GTPase } \\
\text { activation }\end{array}$} \\
\hline 3 & gi|31982030 & Rho GDP-dissociation inhibitor 1 & $26 / 5.2$ & $23,450 / 5.12$ & 114 & 15 & 1.2 & 0.038 \\
\hline \multicolumn{9}{|c|}{ Heme binding } \\
\hline 2 & gi|3724328 & Heme-binding protein & $22 / 5.1$ & $21,165 / 5.18$ & 95 & 14 & 1.3 & 0.023 \\
\hline \multicolumn{9}{|c|}{ Hydrolase } \\
\hline 14 & gi|38371755 & $\begin{array}{l}\mathrm{N}(\mathrm{G}), \mathrm{N}(\mathrm{G}) \text {-dimethylarginine } \\
\text { dimethylaminohydrolase } 1\end{array}$ & $31 / 5.8$ & $\begin{array}{c}31 / 5.8 \\
31,760 / 5.64\end{array}$ & 125 & 8 & 0.7 & 0.011 \\
\hline \multicolumn{9}{|c|}{ Iron storage } \\
\hline 10 & gi|6753912 & Ferritin heavy chain & $18 / 5.5$ & $21,224 / 5.53$ & 237 & 26 & 0.8 & 0.039 \\
\hline \multicolumn{9}{|c|}{$\begin{array}{l}\text { Neurotransmitter } \\
\text { release }\end{array}$} \\
\hline 7 & gi|6678437 & $\begin{array}{l}\text { Translationally controlled } \\
\text { tumor protein }\end{array}$ & $24 / 4.7$ & $19,564 / 4.76$ & 98 & 5 & 0.9 & 0.015 \\
\hline \multicolumn{9}{|c|}{ Protease inhibitor } \\
\hline 4 & gi|84794552 & $\begin{array}{l}\text { Phosphatidylethanolamine- } \\
\text { binding protein } 1\end{array}$ & $21 / 5.1$ & $20,988 / 5.19$ & 168 & 25 & 1.1 & 0.032 \\
\hline \multicolumn{9}{|c|}{ Transcription } \\
\hline 6 & gi|6679299 & Prohibitin & $27 / 5.7$ & $29,859 / 5.57$ & 270 & 20 & 0.9 & 0.038 \\
\hline
\end{tabular}

Spot numbers correspond to the 2-DE gel in Figure 1(a). Accession numbers were obtained from the National Center for Biotechnology Information (NCBI) database. Score and sequence coverage (SC) were obtained by Mascot database searching (http://www.matrixscience.com). $P$ values were obtained by ANOVA, $P<0.05$.

expressed in the brain [29]. The protein level of Prx 2 is increased in aging and AD brains, suggesting that Prx 2 is involved in the elevated neuronal antioxidant response under oxidative stress [30]. The proteomic analysis of the hippocampus in $\mathrm{AD}$ patients shows that the expression of Prx 2 increases compared with age-matched controls [31]. Prx 2deficient mice show remarkably increased susceptibility to oxidative stress-induced tissue damage [32]. Therefore, the increased expression of $\operatorname{Prx} 2$ might decrease oxidative damage, improving abnormalities of neurons and glia in the brain and subsequent dementia.

4.3. Neurotransmitter Release. Translationally controlled tumor protein (TCTP) is a multifunctional protein that is involved in immune responses, cell proliferation, cancer progression, and apoptosis [33]. TCTP, also known as histamine-releasing factor (HRF), induces the secretion of histamine that is widely distributed in the brain [34] 
TABLE 2: Identified proteins in the cortex and their functional categories.

\begin{tabular}{|c|c|c|c|c|c|c|c|c|}
\hline Spot no. & $\begin{array}{c}\text { Accession } \\
\text { no. }\end{array}$ & Identified protein & $\begin{array}{l}\text { Observed Mw } \\
(\mathrm{kDa}) / \mathrm{pI}\end{array}$ & $\begin{array}{l}\text { Theoretical } \\
\text { Mw (Da)/pI }\end{array}$ & Score & SC & $\begin{array}{l}\text { Fold change } \\
\text { (STZ/CTL) }\end{array}$ & $\begin{array}{l}\text { ANOVA } \\
P \text { value }\end{array}$ \\
\hline \multicolumn{9}{|c|}{$\begin{array}{l}\text { Cytoskeletal } \\
\text { protein }\end{array}$} \\
\hline 17 & gi|3642627 & Alpha-tubulin, partial & $40 / 6.1$ & $11,058 / 4.85$ & 70 & 15 & 1.4 & 0.016 \\
\hline 18 & gi|6678469 & Tubulin alpha-1C chain & $31 / 5.6$ & $50,562 / 4.96$ & 187 & 10 & 1.4 & 0.015 \\
\hline 19 & gi|49868 & Put. beta-actin (aa 27-375) & $25 / 5.7$ & $39,446 / 5.78$ & 126 & 8 & 1.3 & 0.035 \\
\hline 22 & gi|809561 & Gamma-actin & $22 / 5.6$ & $41,335 / 5.56$ & 221 & 10 & 1.3 & 0.037 \\
\hline 23 & gi|148539957 & Alpha-internexin & $44 / 5.6$ & $55,520 / 5.35$ & 567 & 19 & 1.2 & 0.045 \\
\hline 33 & gi|7106439 & Tubulin beta- 5 chain & $41 / 4.9$ & $50,095 / 4.78$ & 426 & 12 & 0.7 & 0.031 \\
\hline \multicolumn{9}{|c|}{$\begin{array}{l}\text { Energy } \\
\text { metabolism }\end{array}$} \\
\hline 27 & gi|13879366 & $\begin{array}{c}\text { NADH dehydrogenase } \\
\text { (ubiquinone) Fe-S protein } 1\end{array}$ & $59 / 5.4$ & $80,724 / 5.51$ & 264 & 10 & 0.9 & 0.002 \\
\hline 28 & gi|23272966 & Atp5b protein, partial & $39 / 5.0$ & $56,632 / 5.24$ & 535 & 22 & 0.8 & 0.007 \\
\hline 29 & gi|23272966 & Atp5b protein, partial & $39 / 4.9$ & $56,632 / 5.24$ & 470 & 19 & 0.8 & 0.008 \\
\hline \multicolumn{9}{|c|}{ Glycolysis } \\
\hline 26 & gi|7305027 & Gamma-enolase isoform 1 & $36 / 5.0$ & $47,609 / 4.99$ & 449 & 14 & 0.9 & 0.044 \\
\hline 34 & gi|7305027 & Gamma-enolase isoform 1 & $36 / 4.8$ & $47,609 / 4.99$ & 249 & 11 & 0.6 & 0.004 \\
\hline \multicolumn{9}{|c|}{ Antiapoptosis } \\
\hline 21 & gi|15809030 & Beta-synuclein & $16 / 4.2$ & $14,043 / 4.38$ & 122 & 29 & 1.3 & 0.024 \\
\hline \multicolumn{9}{|c|}{$\begin{array}{l}\text { Calcium ion } \\
\text { binding }\end{array}$} \\
\hline 31 & gi|34098931 & Calretinin & $22 / 4.8$ & $31,467 / 4.94$ & 199 & 15 & 0.8 & 0.008 \\
\hline \multicolumn{9}{|c|}{$\begin{array}{l}\text { Heme metabolic } \\
\text { process }\end{array}$} \\
\hline 30 & gi|4886904 & Heme-binding protein & $20 / 5.2$ & $21,153 / 5.18$ & 170 & 26 & 0.8 & 0.004 \\
\hline \multicolumn{9}{|l|}{$\begin{array}{l}\text { Protease } \\
\text { inhibitor }\end{array}$} \\
\hline 24 & gi|84794552 & $\begin{array}{l}\text { Phosphatidylethanolamine- } \\
\text { binding protein } 1\end{array}$ & $19 / 5.1$ & $20,988 / 5.19$ & 203 & 32 & 0.9 & 0.007 \\
\hline \multicolumn{9}{|c|}{$\begin{array}{l}\text { Protein } \\
\text { degradation }\end{array}$} \\
\hline 25 & gi|6753490 & $\begin{array}{c}\text { COP9 signalosome complex } \\
\text { subunit } 4\end{array}$ & $31 / 5.8$ & $46,541 / 5.57$ & 62 & 4 & 0.9 & 0.035 \\
\hline \multicolumn{9}{|c|}{$\begin{array}{l}\text { Protein } \\
\text { deubiquitination }\end{array}$} \\
\hline 32 & gi|7578956 & $\begin{array}{l}\text { Ubiquitin C-terminal } \\
\text { hydrolase L3 }\end{array}$ & $22 / 4.8$ & $26,333 / 5.08$ & 113 & 9 & 0.8 & 0.008 \\
\hline \multicolumn{9}{|c|}{ Unknown } \\
\hline 20 & gi|74212109 & Unnamed protein product & $29 / 5.5$ & $50,076 / 4.75$ & 246 & 10 & 1.3 & 0.041 \\
\hline
\end{tabular}

Spot numbers correspond to the 2-DE gel in Figure 1(b). Accession numbers were obtained from the National Center for Biotechnology Information (NCBI) database. Score and sequence coverage (SC) were obtained by Mascot database searching (http://www.matrixscience.com). $P$ values were obtained by ANOVA, $P<0.05$.

Histamine-expressing neurons project to wide areas of the brain, including regions especially important for cognitive functions such as the frontal cortex and hippocampus [35]. Histamine and TCTP are significantly reduced in AD brain compared to age-matched control, suggesting that decreased histamine levels impair cognitive function in $\mathrm{AD}$ [35]. Thus, the decreased expression of TCTP might decrease the histamine release and be one of the main causes of dementia.
4.4. Protein Deubiquitination. In humans, four ubiquitin carboxy-terminal hydrolase (UCH) proteins (UCH-L1, UCH-L3, UCH37/UCH-L5, and BAP1) have been identified, but only UCH-L1 and L3 have been studied in detail [36]. $\mathrm{UCH}-\mathrm{L} 1$ is a neuronal deubiquitinase that cleaves peptide adducts from the C-terminus of ubiquitin [37]. UCH-L1 is predominantly expressed in the brain [37]. The proteomic analysis of the hippocampus in A $\beta$ PPswe/PS1dE9 mice 
TABLE 3: Identified phosphoproteins in the hippocampus and cortex, and their functional categories.

\begin{tabular}{|c|c|c|c|c|c|c|c|c|}
\hline Spot no. & $\begin{array}{l}\text { Accession } \\
\text { no. }\end{array}$ & Identified protein & $\begin{array}{l}\text { Observed Mw } \\
(\mathrm{kDa}) / \mathrm{pI}\end{array}$ & $\begin{array}{l}\text { Theoretical } \\
\text { Mw (Da)/pI }\end{array}$ & Score & SC & $\begin{array}{l}\text { Fold change } \\
\text { (STZ/CTL) }\end{array}$ & $\begin{array}{l}\text { ANOVA } \\
P \text { value }\end{array}$ \\
\hline \multicolumn{9}{|c|}{ Hippocampus } \\
\hline \multicolumn{9}{|c|}{$\begin{array}{l}\text { Neuronal } \\
\text { development }\end{array}$} \\
\hline 35 & gi|40254595 & $\begin{array}{l}\text { Dihydropyrimidinase-related } \\
\text { protein } 2\end{array}$ & $44 / 5.6$ & $62,638 / 5.95$ & 85 & 4 & 1.2 & 0.04 \\
\hline 36 & gi|40254595 & $\begin{array}{l}\text { Dihydropyrimidinase-related } \\
\text { protein } 2\end{array}$ & $44 / 5.8$ & $62,638 / 5.95$ & 144 & 6 & 1.1 & 0.015 \\
\hline \multicolumn{9}{|c|}{ Protein degradation } \\
\hline 37 & gi|261824000 & $\begin{array}{l}\text { Proteasome subunit alpha } \\
\text { type- } 3\end{array}$ & $28 / 5.3$ & $28,615 / 5.29$ & 88 & 9 & 0.9 & 0.037 \\
\hline \multicolumn{9}{|c|}{ Vesicular transport } \\
\hline 38 & gi|29789104 & $\begin{array}{l}\text { Beta-soluble NSF attachment } \\
\text { protein }\end{array}$ & $30 / 5.3$ & $33,878 / 5.32$ & 177 & 16 & 0.8 & 0.04 \\
\hline \multicolumn{9}{|l|}{ Cortex } \\
\hline \multicolumn{9}{|c|}{ Cytoskeletal protein } \\
\hline 42 & gi|809561 & Gamma-actin & $43 / 5.3$ & $41,335 / 5.56$ & 254 & 13 & 0.7 & 0.039 \\
\hline \multicolumn{9}{|c|}{$\begin{array}{l}\text { Neuronal } \\
\text { development }\end{array}$} \\
\hline 39 & gi|40254595 & $\begin{array}{l}\text { Dihydropyrimidinase-related } \\
\text { protein } 2\end{array}$ & $45 / 5.9$ & $62,638 / 5.95$ & 490 & 17 & 1.3 & 0.026 \\
\hline \multicolumn{9}{|c|}{ Protein degradation } \\
\hline 41 & gi|261824000 & $\begin{array}{l}\text { Proteasome subunit alpha } \\
\text { type- } 3\end{array}$ & $21 / 5.3$ & $28,615 / 5.29$ & 142 & 14 & 0.8 & 0.043 \\
\hline \multicolumn{9}{|c|}{ Unknown } \\
\hline 40 & gi|70794816 & Enolase $1 \mathrm{~B}$, retrotransposed & $32 / 6.5$ & $47,453 / 6.37$ & 163 & 9 & 1.1 & 0.018 \\
\hline
\end{tabular}

Spot numbers correspond to the 2-DE gel in Figure 2. Accession numbers were obtained from the National Center for Biotechnology Information. (NCBI) database. Score and sequence coverage (SC) were obtained by Mascot database searching (http://www.matrixscience.com). $P$ values were obtained by ANOVA, $P<0.05$.

shows that the expression of UCH-L1 decreases compared with age-matched wild-type mice [38]. UCH-L1 is downregulated in the brain of patients with Parkinson's disease and $\mathrm{AD}$ [39]. The administration of UCH-L1 protein fused to the transduction domain of HIV transactivator (TAT) protein into APP/PS1 model mice of AD provided a protective effect against amyloid-induced neurodegeneration in synaptic function and contextual memory [40]. UCH-L3 is universally expressed in all tissues [41]. UCH-L3-deficient mice exhibit significant impairment in learning and memory using Morris water maze and 8-arm radial maze task [42]. Indeed, our findings showed that UCH-L1 and L3 were downregulated in diabetes-induced dementia. Thus, the decreased expressions of UCH-L1 and L3 could contribute to neurodegeneration, resulting in dementia.

4.5. Antiapoptosis. The human synuclein family has 3 members, $\alpha$-synuclein, $\beta$-synuclein, and $\gamma$-synuclein [43]. $\alpha$-Synuclein and $\beta$-synuclein are predominantly localized at presynaptic nerve terminals in the CNS [44]. In contrast, $\gamma$ synuclein is abundant in the peripheral nervous system [45]. $\beta$-Synuclein protects neurons against apoptosis induced by staurosporine and 6-hydroxydopamine, which is linked to the suppression of p53 transcriptional activity [46]. Thus, the increased expression of $\beta$-synuclein could protect against neuronal apoptosis in diabetes-induced dementia.

4.6. Calcium Ion Binding. Calretinin is an EF-hand calciumbinding protein involved in calcium signaling [47]. Calretinin is expressed in hilar mossy cells and in widely distributed subsets of GABAergic interneurons in the normal mouse hippocampus [48]. Calretinin maintains appropriate calcium ion concentration in cells and participates in the modulation of neuronal activity and synaptic plasticity [49]. Knockout mice lacking calretinin show no alteration in basal synaptic transmission but impaired LTP in the dentate gyrus [48]. These findings indicate that the decreased expression of calretinin might be involved in diabetesinduced dementia.

4.7. Neuronal Development. Dihydropyrimidinase-related protein 2/collapsin response mediator protein 2 (DPYL2/ CRMP2) binds to tubulin heterodimers to promote microtubule formation and stability, resulting in axonal growth and neuronal polarity [50]. Cyclin-dependent kinase $5(\mathrm{Cdk} 5)$ and glycogen syntheses kinase $3 \beta$ (GSK-3 3 ) regulate DPYL2 


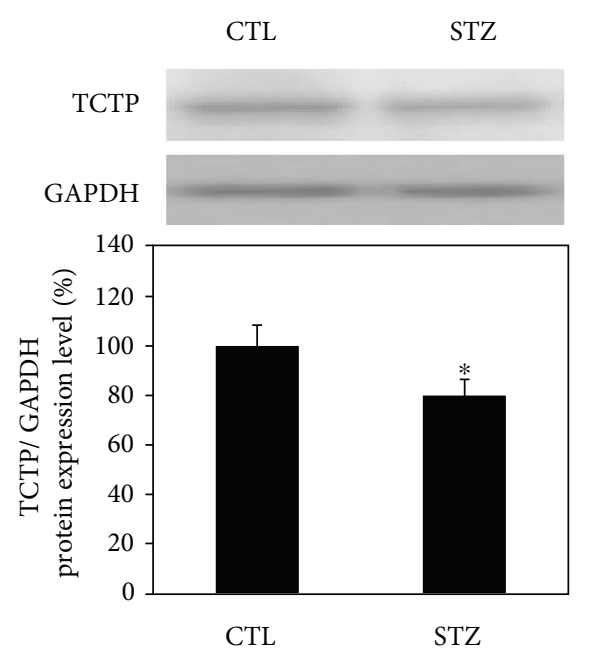

(a)

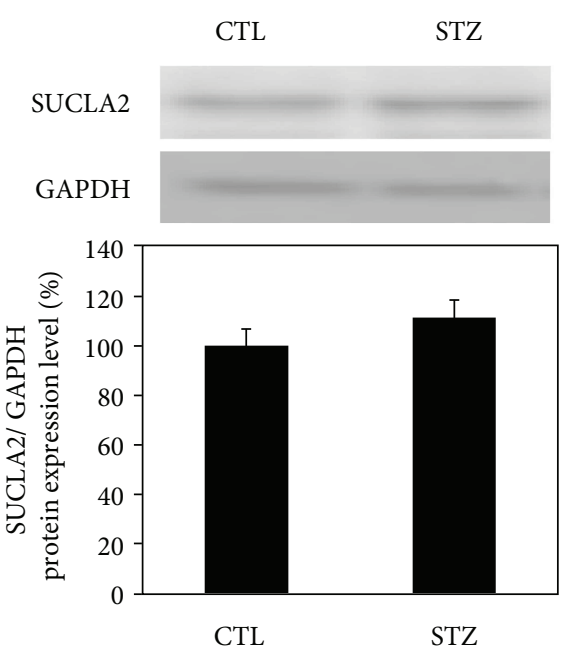

(b)

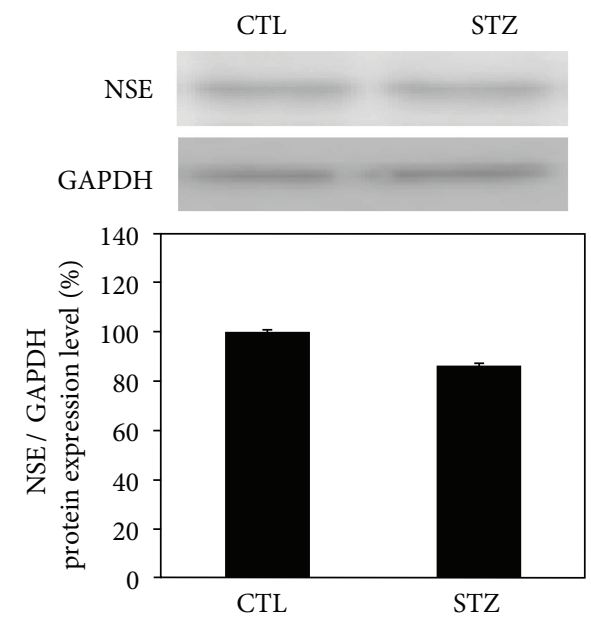

(c)

FIGURE 3: Representative images of Western blotting evaluating the expression of translationally controlled tumor protein (TCTP) (a), ATPspecific succinyl-CoA synthetase beta subunit (SUCLA2) (b) in the hippocampus, and gamma-enolase isoform 1 (NSE) (c) in the cortex from STZ-treated (STZ) and control (CTL) mice. The protein expression levels are normalized to glyceraldehyde 3-phosphate dehydrogenase $(\mathrm{GAPDH})$ expression and indicated as the ratio relative to that in CTL. Data are presented as mean \pm SEM of four independent experiments. Representative bands are shown above each graph. ${ }^{*} P<0.05$ versus control.

activity [51]. The phosphorylation of DPYL2 by GSK-3 $\beta$ can inactivate DPYL2 function [52]. DPYL2 is phosphorylated at Ser522 by Cdk 5 and subsequently at Ser518, Thr514, and Thr509 by GSK- $3 \beta$ in brain tissue from human AD patients and in some mouse models of $\mathrm{AD}[53] . \mathrm{A} \beta_{25-35}$-induced impairment of cognitive function and LTP was not observed in DPYL2 phosphorylation-deficient knock-in mice, in which Ser522 of DPYL2 was replaced with alanine [54], suggesting that the phosphorylation of DPYL2 at Ser522 was associated with $\mathrm{A} \beta_{25-35}$-induced cognitive memory deficit and impairment of LTP. Indeed, our findings showed that phosphorylated DPYL2 was increased in the hippocampus and cortex of STZ-treated mice. Taken together, it is suggested that phosphorylated DPYL2 plays an important role in diabetes-induced dementia. Interestingly, DPYL2 was identified from two phosphoprotein spots on 2-DE gels stained with Pro-Q Diamond staining in the hippocampus.
The shift in the position of these phosphoprotein spots may imply translational modifications such as phosphorylation, acetylation, and degradation.

\section{Conclusion}

In conclusion, we found 32 proteins and 7 phosphoproteins with significantly altered levels in the hippocampus and cortex of STZ-treated mice. We propose that the identified proteins and phosphoproteins might play important roles in the molecular mechanisms involved in diabetesinduced dementia.

\section{Conflicts of Interest}

The authors declare no conflict of interest. 


\section{Acknowledgments}

The authors thank Y. Kitamura (BMRC) for animal maintenance.

\section{References}

[1] American Diabetes Association, "Diagnosis and classification of diabetes mellitus," Diabetes Care, vol. 34, Supplement 1, pp. S62-S69, 2010.

[2] J. S. Roriz-Filho, T. M. Sá-Roriz, I. Rosset et al., "(Pre) diabetes, brain aging, and cognition," Biochimica et Biophysica Acta (BBA) - Molecular Basis of Disease, vol. 1792, no. 5, pp. 432443, 2009.

[3] R. Mastrocola, F. Restivo, I. Vercellinatto et al., "Oxidative and nitrosative stress in brain mitochondria of diabetic rats," Journal of Endocrinology, vol. 187, no. 1, pp. 37-44, 2005.

[4] E. Candeias, A. I. Duarte, C. Carvalho et al., "The impairment of insulin signaling in Alzheimer's disease," IUBMB Life, vol. 64, no. 12, pp. 951-957, 2012.

[5] J. Havrankova, J. Roth, and M. Brownstein, "Insulin receptors are widely distributed in the central nervous system of the rat," Nature, vol. 272, no. 5656, pp. 827-829, 1978.

[6] C. L. Adam, P. A. Findlay, R. P. Aitken, J. S. Milne, and J. M. Wallace, "In vivo changes in central and peripheral insulin sensitivity in a large animal model of obesity," Endocrinology, vol. 153, no. 7, pp. 3147-3157, 2012.

[7] Z. Laron, "Insulin and the brain," Archives of Physiology and Biochemistry, vol. 115, no. 2, pp. 112-116, 2009.

[8] M. A. Reger, G. S. Watson, P. S. Green et al., "Intranasal insulin administration dose-dependently modulates verbal memory and plasma amyloid-beta in memory-impaired older adults," Journal of Alzheimer's Disease, vol. 13, no. 3, pp. 323-331, 2008.

[9] S. M. de la Monte, "Relationships between diabetes and cognitive impairment," Endocrinology and Metabolism Clinics of North America, vol. 43, no. 1, pp. 245-267, 2014.

[10] Y.-F. Mao, Z. Guo, T. Zheng et al., "Intranasal insulin alleviates cognitive deficits and amyloid pathology in young adult APPswe/PS1dE9 mice," Aging Cell, vol. 15, no. 5, pp. 893902, 2016.

[11] J. T. Dou, M. Chen, F. Dufour, D. L. Alkon, and W. Q. Zhao, "Insulin receptor signaling in long-term memory consolidation following spatial learning," Learning \& Memory, vol. 12, no. 6, pp. 646-655, 2005.

[12] H. G. Bernstein, U. Lendeckel, A. Bukowska et al., "Regional and cellular distribution patterns of insulin-degrading enzyme in the adult human brain and pituitary," Journal of Chemical Neuroanatomy, vol. 35, no. 2, pp. 216-224, 2008.

[13] K. Vekrellis, Z. Ye, W. Q. Qiu et al., "Neurons regulate extracellular levels of amyloid beta-protein via proteolysis by insulin-degrading enzyme," Journal of Neuroscience, vol. 20, no. 5, pp. 1657-1665, 2000.

[14] W. Farris, S. Mansourian, M. A. Leissring et al., "Partial loss-of-function mutations in insulin-degrading enzyme that induce diabetes also impair degradation of amyloid betaprotein," American Journal of Pathology, vol. 164, no. 4, pp. 1425-1434, 2004.

[15] T. Szkudelski, "The mechanism of alloxan and streptozotocin action in B cells of the rat pancreas," Physiological Research, vol. 50, no. 6, pp. 537-546, 2001.
[16] M. C. Deeds, J. M. Anderson, A. S. Armstrong et al., "Single dose streptozotocin-induced diabetes: considerations for study design in islet transplantation models," Laboratory Animals, vol. 45, no. 3, pp. 131-140, 2011.

[17] M. Radenkovic, M. Stojanovic, and M. Prostran, "Experimental diabetes induced by alloxan and streptozotocin: the current state of the art," Journal of Pharmacological and Toxicological Methods, vol. 78, pp. 13-31, 2016.

[18] Y. Wang, L. Wu, J. Li et al., "Synergistic exacerbation of mitochondrial and synaptic dysfunction and resultant learning and memory deficit in a mouse model of diabetic Alzheimer's disease," Journal of Alzheimer's Disease, vol. 43, no. 2, pp. 451-463, 2015.

[19] J. J. Ramos-Rodriguez, O. Ortiz, M. Jimenez-Palomares et al., "Differential central pathology and cognitive impairment in pre-diabetic and diabetic mice," Psychoneuroendocrinology, vol. 38, no. 11, pp. 2462-2475, 2013.

[20] H. S. Fox, "Androgen treatment prevents diabetes in nonobese diabetic mice," The Journal of Experimental Medicine, vol. 175, no. 5, pp. 1409-1412, 1992.

[21] K. Matsuura, M. Otani, M. Takano, K. Kadoyama, and S. Matsuyama, "The influence of chronic nicotine treatment on proteins expressed in the mouse hippocampus and cortex," European Journal of Pharmacology, vol. 780, pp. 16-25, 2016.

[22] M. Takano, T. Yamashita, K. Nagano et al., "Proteomic analysis of the hippocampus in Alzheimer's disease model mice by using two-dimensional fluorescence difference in gel electrophoresis," Neuroscience Letters, vol. 534, pp. 85-89, 2013.

[23] P. Penzes, D. P. Srivastava, and K. M. Woolfrey, "Not just actin? A role for dynamic microtubules in dendritic spines," Neuron, vol. 61, no. 1, pp. 3-5, 2009.

[24] G. P. Shumyatsky, G. Malleret, R. M. Shin et al., "Stathmin, a gene enriched in the amygdala, controls both learned and innate fear," Cell, vol. 123, no. 4, pp. 697-709, 2005.

[25] P. Hotulainen and C. C. Hoogenraad, "Actin in dendritic spines: connecting dynamics to function," Journal of Cell Biology, vol. 189, no. 4, pp. 619-629, 2010.

[26] T. Krucker, G. R. Siggins, and S. Halpain, "Dynamic actin filaments are required for stable long-term potentiation (LTP) in area CA1 of the hippocampus," Proceedings of the National Academy of Sciences, vol. 97, no. 12, pp. 6856-6861, 2000.

[27] S. G. Rhee, S. W. Kang, T. S. Chang, W. Jeong, and K. Kim, "Peroxiredoxin, a novel family of peroxidases," IUBMB Life, vol. 52, no. 1, pp. 35-41, 2001.

[28] C. Espinosa-Diez, V. Miguel, D. Mennerich et al., "Antioxidant responses and cellular adjustments to oxidative stress," Redox Biology, vol. 6, pp. 183-197, 2015.

[29] T. A. Sarafian, M. Anthony Verity, H. V. Vinters et al., "Differential expression of peroxiredoxin subtypes in human brain cell types," Journal of Neuroscience Research, vol. 56, no. 2, pp. 206-212, 1999.

[30] A. Patenaude, M. R. V. Murthy, and M. -E. Mirault, "Emerging roles of thioredoxin cycle enzymes in the central nervous system," Cellular and Molecular Life Sciences, vol. 62, no. 10, pp. 1063-1080, 2005.

[31] R. Sultana, D. Boyd-Kimball, J. Cai et al., "Proteomics analysis of the Alzheimer's disease hippocampal proteome," Journal of Alzheimers Disease, vol. 11, no. 2, pp. 153-164, 2007.

[32] T. H. Lee, S. U. Kim, S. L. Yu et al., "Peroxiredoxin II is essential for sustaining life span of erythrocytes in mice," Blood, vol. 101, no. >12, pp. 5033-5038, 2003. 
[33] M. Gnanasekar, S. Thirugnanam, G. Zheng, A. Chen, and K. Ramaswamy, "Gene silencing of translationally controlled tumor protein (TCTP) by siRNA inhibits cell growth and induces apoptosis of human prostate cancer cells," International Journal of Oncology, vol. 34, no. 5, pp. 1241-1246, 2009.

[34] S. M. Macdonald, "Potential role of histamine releasing factor (HRF) as a therapeutic target for treating asthma and allergy," Journal of Asthma and Allergy, vol. 5, pp. 51-59, 2012.

[35] A. Zlomuzica, D. Dere, S. Binder, M. A. De Souza Silva, J. P. Huston, and E. Dere, "Neuronal histamine and cognitive symptoms in Alzheimer's disease," Neuropharmacology, vol. 106, pp. 135-145, 2016.

[36] Z. M. Eletr and K. D. Wilkinson, "Regulation of proteolysis by human deubiquitinating enzymes," Biochimica et Biophysica Acta (BBA) - Molecular Cell Research, vol. 1843, no. 1, pp. 114-128, 2014.

[37] C. N. Larsen, B. A. Krantz, and K. D. Wilkinson, "Substrate specificity of deubiquitinating enzymes: ubiquitin C-terminal hydrolases," Biochemistry, vol. 37, no. 10, pp. 3358-3368, 1998.

[38] Y. Fu, D. Zhao, B. Pan et al., "Proteomic analysis of protein expression throughout disease progression in a mouse model of Alzheimer's disease," Journal of Alzheimer's Disease, vol. 47, no. 4, pp. 915-926, 2015.

[39] J. Choi, A. I. Levey, S. T. Weintraub et al., "Oxidative modifications and down-regulation of ubiquitin carboxyl-terminal hydrolase L1 associated with idiopathic Parkinson's and Alzheimer's diseases," Journal of Biological Chemistry, vol. 279, no. 13, pp. 13256-13264, 2004.

[40] B. Gong, Z. Cao, P. Zheng et al., "Ubiquitin hydrolase Uch-L1 rescues beta-amyloid-induced decreases in synaptic function and contextual memory," Cell, vol. 126, no. 4, pp. 775-788, 2006.

[41] L. J. Kurihara, E. Semenova, J. M. Levorse, and S. M. Tilghman, "Expression and functional analysis of Uch-L3 during mouse development," Molecular and Cellular Biology, vol. 20, no. 7, pp. 2498-2504, 2000.

[42] M. A. Wood, M. P. Kaplan, C. M. Brensinger, W. Guo, and T. Abel, "Ubiquitin C-terminal hydrolase L3 (Uchl3) is involved in working memory," Hippocampus, vol. 15, no. 5, pp. 610-621, 2005.

[43] Y. H. Sung and D. Eliezer, "Residual structure, backbone dynamics, and interactions within the synuclein family," Journal of Molecular Biology, vol. 372, no. 3, pp. 689-707, 2007.

[44] R. Jakes, M. G. Spillantini, and M. Goedert, "Identification of two distinct synucleins from human brain," FEBS Letters, vol. 345, no. 1, pp. 27-32, 1994.

[45] A. N. Akopian and J. N. Wood, "Peripheral nervous systemspecific genes identified by subtractive cDNA cloning," Journal of Biological Chemistry, vol. 270, no. 36, pp. 21264-21270, 1995.

[46] C. A. da Costa, E. Masliah, and F. Checler, "Beta-synuclein displays an antiapoptotic p53-dependent phenotype and protects neurons from 6-hydroxydopamine-induced caspase 3 activation: cross-talk with alpha-synuclein and implication for Parkinson's disease," Journal of Biological Chemistry, vol. 278, no. 39, pp. 37330-37335, 2003.

[47] J. H. Rogers, "Calretinin: a gene for a novel calcium-binding protein expressed principally in neurons," Journal of Cell Biology, vol. 105, no. 3, pp. 1343-1353, 1987.
[48] S. Schurmans, S. N. Schiffmann, H. Gurden et al., "Impaired long-term potentiation induction in dentate gyrus of calretinin-deficient mice," Proceedings of the National Academy of Sciences, vol. 94, no. 19, pp. 10415-10420, 1997.

[49] K. Rycerz, A. Krawczyk, J. Jaworska-Adamu, and I. KrawczykMarc, "Effects of monosodium glutamate treatment on calretinin-immunoreactive neurons in hippocampus of postnatal rats," Folia Histochemica et Cytobiologica, vol. 52, no. 4, pp. 281-288, 2014.

[50] N. Arimura, C. Menager, Y. Kawano et al., "Phosphorylation by rho kinase regulates CRMP-2 activity in growth cones," Molecular and Cellular Biology, vol. 25, no. 22, pp. 9973 9984, 2005.

[51] Y. Uchida, T. Ohshima, Y. Sasaki et al., "Semaphorin3A signalling is mediated via sequential Cdk5 and GSK3beta phosphorylation of CRMP2: implication of common phosphorylating mechanism underlying axon guidance and Alzheimer's disease," Genes to Cells, vol. 10, no. 2, pp. 165-179, 2005.

[52] T. Yoshimura, Y. Kawano, N. Arimura, S. Kawabata, A. Kikuchi, and K. Kaibuchi, "GSK- $3 \beta$ regulates phosphorylation of CRMP-2 and neuronal polarity," Cell, vol. 120, no. 1, pp. 137-149, 2005.

[53] A. R. Cole, W. Noble, L. van Aalten et al., "Collapsin response mediator protein-2 hyperphosphorylation is an early event in Alzheimer's disease progression," Journal of Neurochemistry, vol. 103, no. 3, pp. 1132-1144, 2007.

[54] T. Isono, N. Yamashita, M. Obara et al., "Amyloid- $\beta_{25-35}$ induces impairment of cognitive function and long-term potentiation through phosphorylation of collapsin response mediator protein 2," Neuroscience Research, vol. 77, no. 3, pp. 180-185, 2013. 


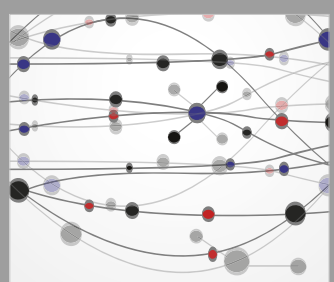

The Scientific World Journal
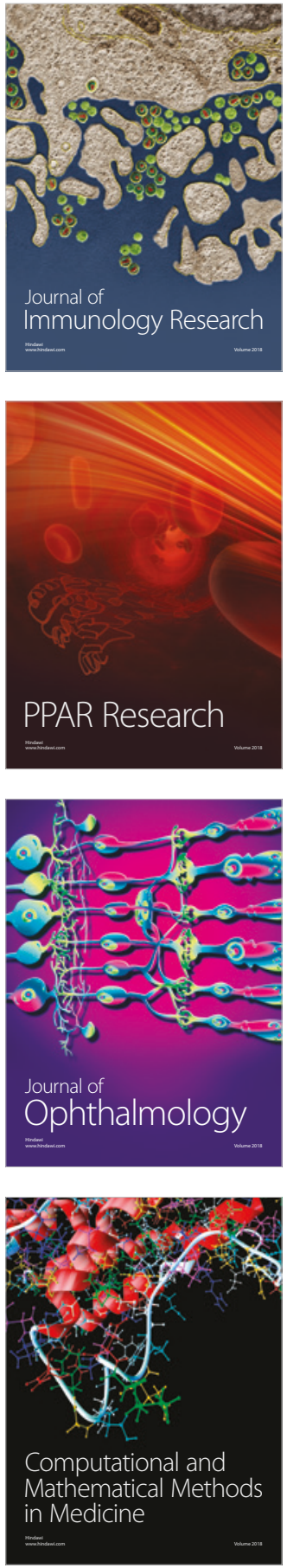

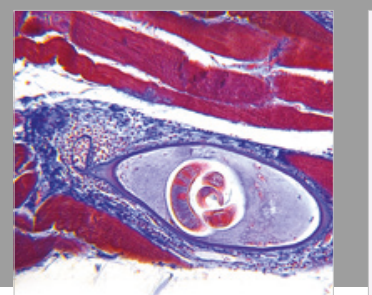

Gastroenterology Research and Practice

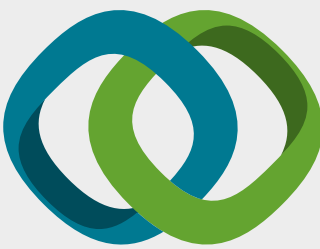

\section{Hindawi}

Submit your manuscripts at

www.hindawi.com
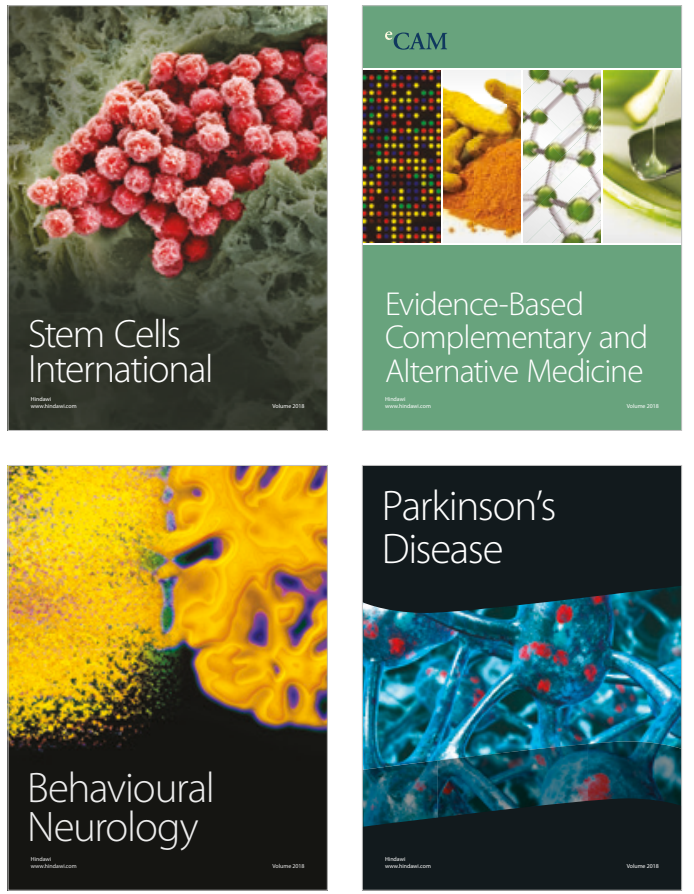

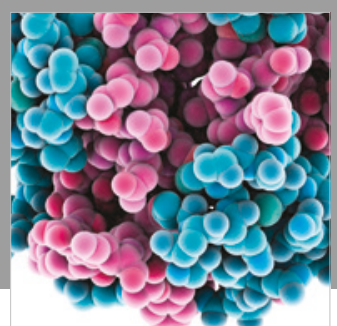

ournal of

Diabetes Research

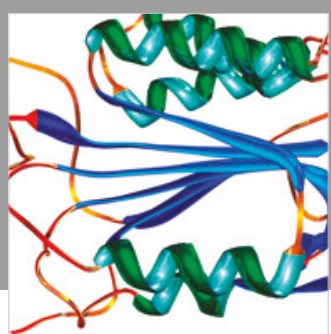

Disease Markers
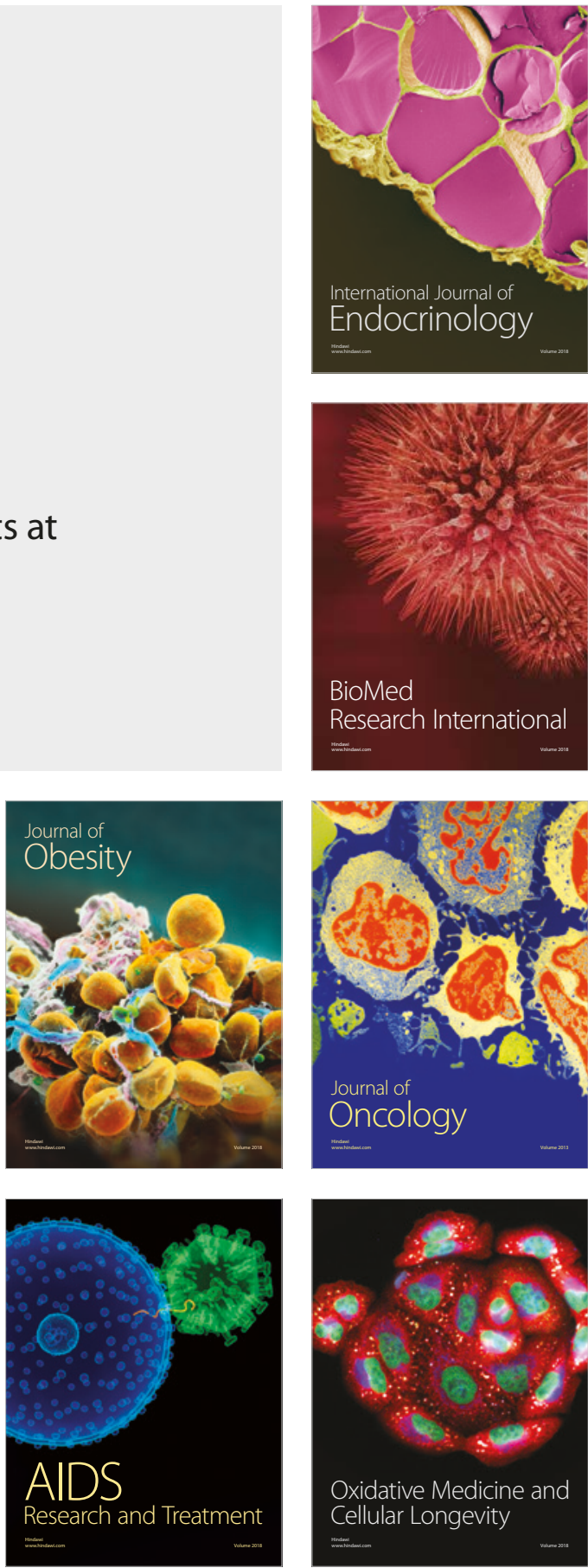